\title{
А.М. Куртяну
}

ПОМОЩЬ В РЕСПУБЛИКЕ МОЛДОВА

Общественное Медицинское Учреждение

Институт Матери и Ребенка

(г. Кишинев, Республика Молдова)

Резюме. Одним из направлений Национальной программы по улучщению и модернизации медицинской перинатальной помощчи (1998-2014 г2.), было внедрение трехуровневой региональной системы неонатальной помощзи, состоящей из 27 перинатальных иеетров (ПЦ) І-го уровня, 10 ПЦ ІІ-го уровня и одного ПЦ ІІІ-го уровня.

Цель работы: изучить накопленный опыт внедрения системы региональной медицинской неонатальной помощчи путем комплексного изучения региональной дифференциации распределения родов и показателей перинатальной смертности.

Материалы и методы. Была изучена рождаемость и показатели перинатальной смертности за период 2001 - 2013 г2. по уровням перинатальной помощчи и рассчитан индекс неонатальных трансферов (ИНТ).

Результаты исследования. Анализ распределения родов показывает увеличение удельного веса принятых родов из общего их количества на III и II уровне ухода: 14,8\% в 2013 г. по сравнению с 9,6\% в 2001 г. (III уровень) и 50,6\% в 2013 г. по сравнению с 38,8\% в 2001 г. (ІІ уровень). В то же время, \% принятых родов на I уровне снизился с показателя 46,2\% до 34,6\%. На ІІІ уровне в 3 раза (с 1,33\% до 2,71\%) увеличилось количество детей, родившихся живыми с весом <1500 г, на I и II уровне отмечается значительное снижение данного показателя. В 2004-2012 гг. число детей, рожденных до 32 недель беременности (н.б.) на I и II уровне, и были доставлены на III-й уровень с весом $\leq 999$ г, увеличилось с 4,2\% до 7,0\%, с весом 1000-1499 г. - не изменилось (32,1\% и 35,6\%), а с весом $\geq 1500$ г. - снизилось с 63,3\% до 57,3\%. ИНТ варьировал от 0,39\% до 0,36\% за этот период, что указывает на хорошее функиионирование службы транспортировки новорожденных.

Выводы. Региональная перинатальная система доказала свою высокую эффективность вместе с внедрением национальных политик, эффективных технологий перинатального ухода и протоколов, основанных на доказательствах, а также обучения медицинского персонала для улучшения материнского и неонатального ухода.

Ключевые слова: регионализация; уровень ухода; новорожденный; направление; транспортировка.

\section{Введение}

Важнейшими направлениями государственной политики любого государства являются охрана материнства и детства, повышение рождаемости и снижение общей смертности населения, материнской и младенческой заболеваемости и смертности. Ключевым звеном в системе оказания квалифицированной медицинской помощи беременным, роженицам, родильницам и новорожденным детям является система регионализации. Среди стратегий улучшения перинатального и неонатального здоровья совершенствованию организации системы направления на получение специализированной помощи и для женщин, и для новорожденных (региональный подход ухода) принадлежит одно из основополагающих мест $[1,2]$. Регионализация также является одним из принципов перинатальной помощи [3].

Республика Молдова достигла больших успехов в снижении неонатальной смертности и заболеваемости, даже в условиях ограниченных ресурсов, что объясняется внедрением множества системных и клинических вмешательств [4]. Показатель ранней неонатальной смертности снизился приблизительно на 50\% в период 1990-2014 гг. (с 15,8\% до 7,5\%о в весовой категории > 1000 г. и с $24,2 \%$ до $10,5 \%$ в весовой категории от 500 г) и составил 3,5 на 1000 детей, родившихся живыми в 2014 году.

Одним из основных стратегических направлений Национальной программы по улучшению и модернизации медицинской неонатальной помощи в Республике Молдова в период 1998-2014 гг. было внедрение региональной системы неона- тальной помощи: направление новорожденных из групп риска на соответствующий уровень оказания медицинских услуг и внедрения транспортировки «in utero» [5].

Региональная система неонатальной помощи была создана в Республике Молдова в 1998 году, учитывая высокую эффективность внедрения регионализации в разных странах [6]. На начальном этапе была разработана органиграмма медицинских перинатальных услуг с системой коммуникаций и критерии для направления и транспортировки новорожденных в зависимости от групп риска [7]. Параллельно внедрению системы регионализации, происходило усиление инфраструктуры роддомов, процесса транспортировки, а также системы сбора и передачи информации. В периоды 1998-2001 гг., 2007 г., 2009 г. и 2012 г. перинатальные центры (ПЦ) I, II и III уровня были оснащены оборудованием для оказания медицинской помощи при неотложных акушерских и неонатальных состояниях, а также для основного ухода за женщинами и новорожденными. Помимо этого, отделения реанимации и интенсивной терапии для новорожденных (ОРиИТН) II и III уровня были оснащены современным оборудованием для лечения недоношенных и больных новорожденных (аппараты для респираторной поддержки, мониторы, аппаратура для диагностики патологий периода новорожденности). Два отделения реанимации и интенсивной терапии для новорожденных в Институте Матери и Ребенка (ИМиР) были капитально отремонтированы. Была создана система обслуживания и поддерживания медицинской аппаратуры. Также, в 2001 
году была разработана и в 2006 году пересмотрена национальная политика в перинатологии, состоящая из трех гидов: А - принципы организации перинатальной службы, Б - Регионализация Перинатальной Службы: уровни и содержание и С - клинические протоколы по акушерству и неонатологии. Медицинский персонал был обучен принципам эффективной неонатальной помощи и использованию современных технологий.

Цель работы: изучить накопленный опыт внедрения системы региональной медицинской неонатальной помощи путем комплексного изучения региональной дифференциации распределения родов и показателей перинатальной смертности.

\section{Материалы и методы}

Использовались статистические отчеты Министерства Здравоохранения и показатели департаментальной статистики за период 2001 - 2013 гг. для изучения рождаемости, показателей перинатальной и неонатальной смертности. Был проведен сравнительный анализ родов по уровням перинатальной помощи за два периода времени 2001г. и 2011-2012 гг. Для этого все ПЦ II уровня были разделены на две категории: продвинутые (более оснащенные медицинским оборудованием и кадрами) и базовые (менее оснащенные оборудованием и кадрами).

Показатели перинатальной смертности изучались с помощью матрицы Babies (Приложение №5 к статистической триместриальной форме 30 «Седения о детях, родившихся и умерших в возрасте до одного года»). Пропорциональный показатель перинатальной смертности (ПС) рассчитывался как пропорция мертворожденных и умерших в ранний неонатальный период новорожденных, в определенной весовой категории, от всех родов (мертворожденных и живорожденных). Специфический показатель ПС рассчитывался как пропорция мертворожденных и умерших в ранний неонатальный период новорожденных, в определенной весовой категории, из всех случаев мертворождаемости и живорожденности в данной весовой категории.

Был рассчитан индекс неонатальных трансферов (ИНТ), который выражает количество новорожденных транспортированных, на 100 живорожденных.

\section{Результаты и их обсуждение}

Структура региональной неонатальной помощи в республике включает акушерские стационары трёх уровней, оказывающих медицинские услуги матерям и новорожденным. 38 родовспомогательных учреждений разделены на 27 родильных домов I уровня, 10 перинатальных центров (ПЦ) II уровня, классифицированых на две категории: 3 - продвинутые и 7 - базовые ПЦ, и ИМиР, который представляет собой III уровень перинатальных услуг.

I УРОВЕНЬ. Медицинские учреждения данного уровня обеспечивают стационарными медицинскими услугами беременных женщин, без имевших место в прошлом акушерских осложнений, родовспоможение при нормальных ро- дах на сроках в 38-42 недель беременности (н.б.) или с малым риском. Уход за здоровыми и больными новорожденными в родильном доме І-го уровня проводится в отделении для совместного пребывания матери и ребенка. Обслуживаемый контингент новорожденных: здоровые новорожденные с весом 2500 г и более при рождении. Больные новорожденные с этого уровня транспортируются на II или III уровни в зависимости от тяжести их состояния (согласно разработанным для каждого уровня критериям).

II УРОВЕНЬ. На данном уровне обеспечивается оказание перинатальных медицинских услуг беременным женщинам, имеющих умеренный акушерский риск, ведение родов на сроке в 32-37 н.б. и уход за новорожденными, чей вес при рождении (в.р.) составил 1800-2500 г. Оказание помощи матерям и новорожденным осуществляется мультидисциплинарной командой - врачами: акушером-гинекологом, неонатологом и терапевтом. Все ПЦ II уровня также совмещают функции центров I уровня на территории своего размещения. В структуре ПЦ II уровня для ухода и лечения новорожденных имеются: отделение совместного пребывания матери и ребенка, а также ОРиИТН и отделения выхаживания недоношенных новорожденных с в.р. $>1800$ г. Штат этого уровня включает круглосуточно дежурящего врача неонатолога, имеющего подготовку и опыт по необходимому неонатальному уходу в случае среднетяжелых заболеваний и неотложных состояний новорожденных. Обслуживаемый контингент новорожденных: здоровые новорожденные, родившиеся на этом уровне; больные дети со среднетяжелыми состояниями, родившиеся на этом уровне; транспортированные новорожденные c I уровня и недоношенные новорожденные с в.p. $>1800$ г для их выхаживания. Дети, рожденные в тяжелом состоянии, транспортируются после первичной стабилизации специализированным транспортом в ОРиИТН III уровня.

III УРОВЕНЬ. На данном уровне обеспечивается оказание перинатальных услуг женщинам, подверженным повышенному акушерскому риску, ведение родов на сроках 22-32 н.б., а также уход за новорожденными, вес которых при родах 1800 г и ниже. Перинатальные медицинские услуги III уровня оказываются ПЦ ИМиР, которому отводится роль Перинатального центра III уровня для обслуживания территории всей страны и, одновременно с этим, ПЦ II уровня для примыкающих к г. Кишиневу районов.

В структуре ПЦ ИМиР для ухода и лечения новорожденных имеются: ОРиИТ новорожденных роддома ИМиР и отделения специализированного ухода за новорожденными 2-го этапа: отделение по уходу за недоношенными новорожденными с весом 500 - 1499 г с постом РиИТ; отделение по уходу за недоношенными с весом 1500 г и больше; отделения патологии, неврологии и хирургии новорожденных. Обслуживаемый контингент новорожденных: здоровые новорожденные, родившиеся на этом уровне, обслуживаются также как в ПЦ I и II уровня, новорожденные от матерей с высоким риском преждевременных родов, транспортированные со всей республики, начиная 
от 500 г при рождении (22 н.б.), а также больные новорожденные в тяжелом состоянии с I и II уровня. Этот контингент новорожденных транспортируется в ИМиР на специализированной машине скорой помощи. Предпочтение отдается транспортировке «in utero» для обеспечения рождения новорожденных с экстремально низкой массой тела в оптимальных условиях и их дальнейшего выхаживания.

Анализ распределения родов по уровням показывает, что с 2001 по 2013 годы на III и II уровне ухода увеличился удельный вес принятых родов их общего их количества: 9,6\% в 2001 г. и, соответственно, 14,8\% в 2013 г. (III уровень) и $38,8 \%$ в 2001 г., соответственно, 50,6\% в 2013 г (II уровень). При этом, \% принятых родов на I уровне снизился за 13 лет с 46,2\% в 2001 г. до $34,6 \%$ в 2013 г. Эта динамика указывает на более налаженное функционирование региональной перинатальной помощи, что практически полностью соответствует распределению, предусмотренному программой, уровню оснащения ПЦ медицинским оборудованием и укомплектованностью персоналом (рис. 1).

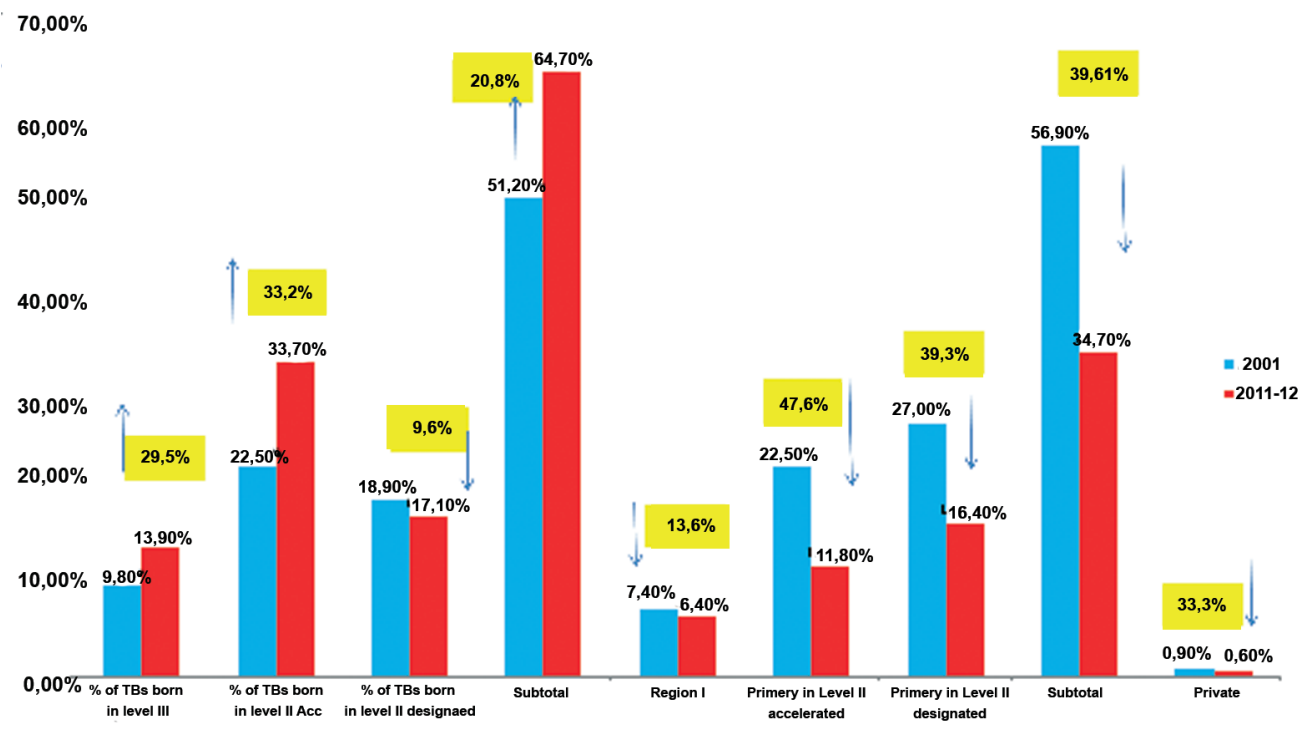

Рис.1. Распределение родов (\%) по уровням региональной системы, 2001 г. и 2011-2012 гг.

Во времени наблюдается увеличение на 33,2\% числа родившихся в продвинутых ПЦ II уровня - с 22,5\% в 2001 г. до 33,7\% в 2012 г., в то время как в базовых ПЦ число родов уменьшилось с 18,9\% в 2001 г. до 17,1\% в 2011-2012 гг. Таким образом, произошло увеличение числа родов на II и III уровне перинатальной помощи на $20,8 \%$ (с 51,2\% с 2001 г. до 64,7\% в 2012 г.). Анализ \% родов на I уровне выявил снижение числа рождений на $39,6 \%$, с $34,7 \%$ (2001 г.) до $56,9 \%$ (2012 г.), с наибольшим снижением в ПЦ І уровня, прикрепленным к продвинутым ПЦ II уровня. Увеличение количества родов на II и III уровне и снижение на I уровне является результатом улучшения направления беременных женщин, в зависимости от риска во время беременности, на соответствующий уровень ухода.

Одним из наиболее важных параметров здоровья рождающегося потомства является структура новорожденных по массе тела при рождении, поскольку масса тела родившегося ребенка характеризует условия внутриутробного развития плода и является интегральным показателем состояния репродуктивного здоровья женщины, течения гестационного процесса и качества жизни матери. Именно поэтому число родившихся детей с низкой массой тела (менее 2500 г) является объективным критерием социально-экономического благополучия населения [1].

Анализ динамики \% живых недоношенных детей, рожденных на всех уровнях перинатальной помощи, выявил следующие моменты: определяется со- кращение рождения живых новорожденных до 2500 гр. в продвинутых ПЦ II уровня в 1,2 раза (с $6,7 \%$ (545 детей) до 5,24\% (703 детей)), в то время как в базовых ПЦ сокращение частоты рождения детей с весом до 2500 гр. происходило в 1,4 раза (с 5,46\% (379 детей) до 3,93\% (393 детей)). Анализ этих показателей в роддомах I-го уровня, прикрепленных к продвинутым ПЦ II уровня, показал снижение количества недоношенных детей с весом до 2500 г от $3,4 \%$ до 2,1\%, в роддомах I уровня, прикрепленных к базовыми ПЦ, с4,6\% до 3,1\% (рис. 2).

Что касается детей, родившихся живыми с весом меньше 1500 г, с учётом распределения по уровням перинатальной помощи, отмечается положительная динамика на III уровне перинатальной помощи, где в течение отчетного периода увеличилось количество детей в данной весовой категории в 3 раза (с 1,33\% до 2,71\%); в продвинутых ПЦ отмечается снижение показателей с $1,02 \%$ до $0,64 \%$; и в базовых ПЦ имеет место сокращение родов в этой весовой категории ст $0,43 \%$ до $0,28 \%$; и на I уровне отмечается значительное снижение показателей (рис. 3 ).

Учитывая, что на III уровень ухода направляются беременные женщины со сроком до 32 н.б., на этом уровне концентрируются практически все роды с этим гестационным сроком и транспортируются все больные и недоношенные новорожденные, что в какой-то мере способствовало увеличению доли смертей новорожденных на этом уровне из общего показателя ранней нео- 


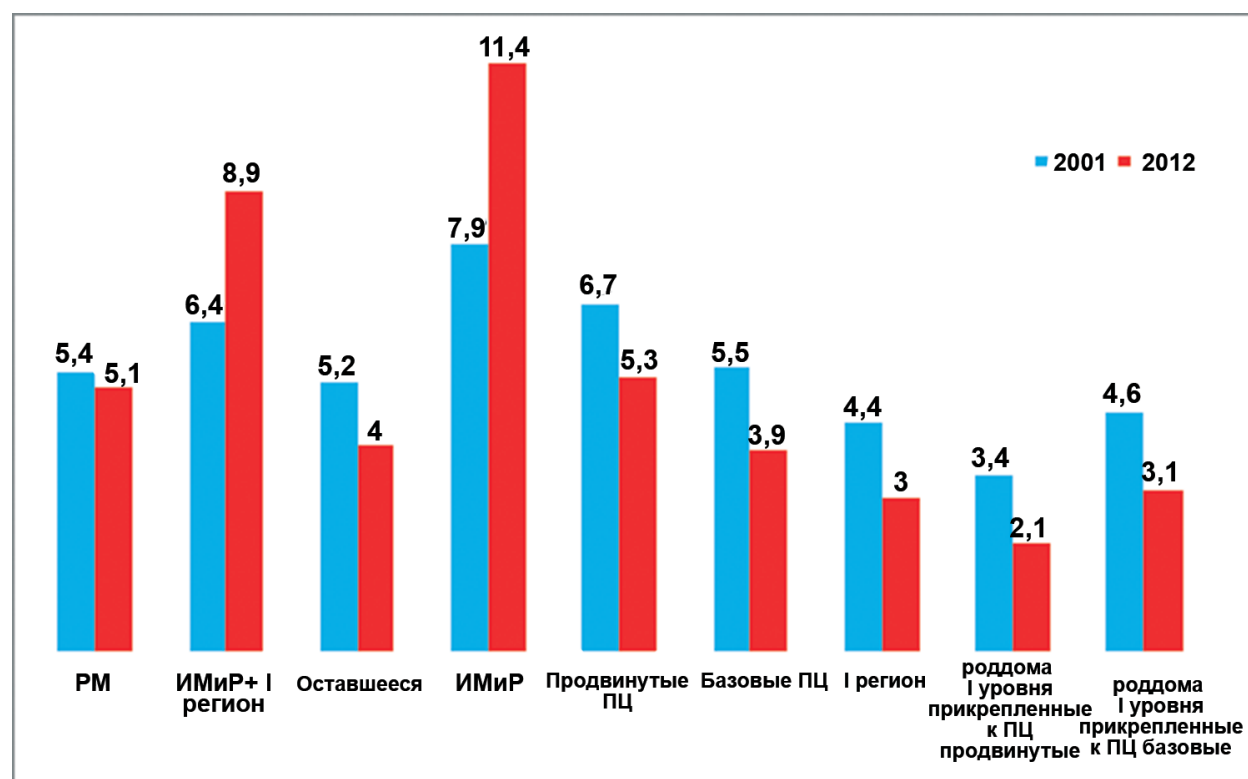

Рис.2. \% распределение живых недоношенных детей ( $\leq 2500$ г.) по уровням региональной системы, 2001г. и 2011-2012 гг

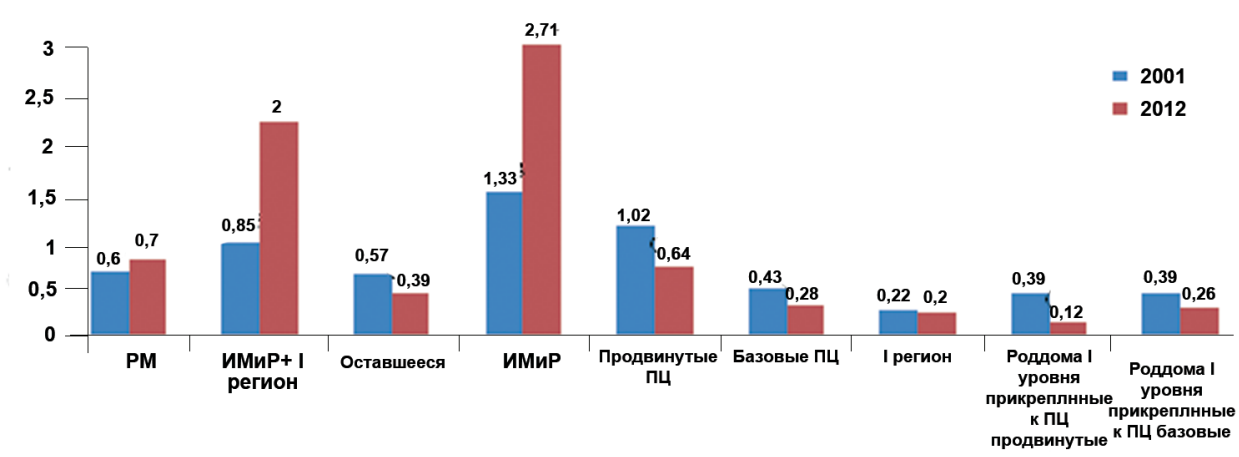

Рис.3. \% распределение живых недоношенных детей ( $\leq 1500$ г.) по уровням региональной системы, 200г.1 и 2011-2012 гг.

натальной смертности - с 30,8\% в 2001 г. до 40,2\% в 2013 г.. На II и I уровнях отмечается противоположная динамика в сторону снижения доли умерших новорожденных: 41,3\% новорожденных умерло в 2001 г. по сравнению с 46,3\% новорожденных в 2013 г. на II уровне и 27,7\% новорожденных умерло в 2001 г., по сравнению с 13,5\% новорожденных в 2013 г., на I уровне.

Вопрос о централизации родов дискутировался десятилетиями научным сообществом, что привело к общему соглашению о преимуществах регионализации для родов с повышенным риском или новорожденных с малым сроком гестации. Анализ данных позволяет отметить некоторый прогресс среди женщин с риском преждевременных родов до 32 н.б., направленных на III уровень в 2013 г. (79,7\%), по сравнению с 2007 г. (61\%). Все же статистические данные указывают на то, что медицинский персонал не всегда учитывает критерии направления беременных женщин из групп риска на соответствующий уровень, а неадекватная оценка риска и запоздалое направление ставят под угрозу здоровье и жизнь беременной женщины и ее будущего ребенка.

По данным, представленным в табл. 1, за пе- риод 2004 - 2012 гг. число детей, рожденных до 32 н.б. на I и II уровне и были доставлены на III уровень перинатального ухода в весовой категории $\leq 999$ г, увеличилось с $4,2 \%$ до 7,0\%, в категории веса 1000-1499 г практически не изменилось $(32,1 \%$ и $35,6 \%)$, а в категории $\geq 1500$ г наблюдалось снижение показателя с $63,3 \%$ до $57,3 \%$.

Для оценки оптимального количества транспортировок в год и для контроля стоимости существует индекс неонатальных трансферов (ИНТ). Низкий ИНТ $(<1 \%)$ показывает хорошо действующее распределение перинатальных учреждений и хорошо организованные службы материнских и неонатальных трансферов. ИРТ варьировал от $0,39 \%$ до $0,36 \%$ за этот период, что указывает на хорошее функционирование службы транспортировки новорожденных.

Качество функционирования системы было измерено по результатам анализа специфических показателей перинатальной смертности (СППС) в зависимости от веса при рождении. Анализ СППС выявил его снижение на 19,71\% (с $939,6 \%$ до $725,3 \%$ ) в весовой категории до 1000 г и на $31,23 \%$ в весовой категории 1000-1499 г (с 
437,5\% до 319,4\%о).

Ниже приводим данные по уровням перинатальной помощи (рис. 4). На III уровне перинатальной помощи отмечается сокращение СППС в весовой категории до 1000 г на 35,9\% (с 999\%о до $640 \%$ ) и на $53,1 \%$ в весовой категории 1000 1499 г (с 529\%о до 248\%о). На II уровне отмечается снижение СППС на $21,8 \%$ в группе детей с весом до 1000 г в продвинутых ПЦ (с 975\% в 2001 г. до 761,9\%о в 2012 г.). В группе детей с весом 1000-1499 г имеет место снижение показателя в обеих группах ПЦ: на $38,7 \%$ в базовых ПЦ (с 476,2\%о в 2001 г. до 291,7\%о в 2012 г.) и на
$20 \%$ - в продвинутых ПЦ (с 347,8\%о в 2001 г. до $278,8 \%$ в 2012 г.), что не является существенным в последнем случае, возможно, связано с направлением этих детей на III уровень перинатальной помощи. В ПЦ I уровня в группе детей с весом до 1000 г отмечается снижение СППС до $11 \%$ (с $963 \%$ в 2001 г. до $857,1 \%$ в 2012 г.) в прикрепленным к продвинутым ПЦ II уровня и на $32,2 \%$ в родильных домах, входящих в состав базовых ПЦ ІІ уровня (с 984\%о в 2001 г. до $666,7 \%$ в 2012 г.). В весовой категории 10001499 г отмечается увеличение этого показателя во всех ПЦ І уровня примерно на $30 \%$.

Таблица 1

Динамика неонатальных трансферов с I и II уровня на III уровень ухода, 2004-2012 гг.

\begin{tabular}{|c|c|c|c|c|c|c|c|c|c|c|}
\hline \multicolumn{2}{|c|}{$\begin{array}{c}\text { Вес при рождении / } \\
\text { Годы }\end{array}$} & 2004 & 2005 & 2006 & 2007 & 2008 & 2009 & 2010 & 2011 & 2012 \\
\hline \multirow{2}{*}{$\leq 999$ г } & № & 6 & 5 & 5 & 8 & 6 & 9 & 7 & 4 & 10 \\
\hline & $\%$ & 4,2 & 3,1 & 3,0 & 4,9 & 3,9 & 5,9 & 4,7 & 2,9 & 7,0 \\
\hline \multirow{2}{*}{$1000-1499$ г } & № & 46 & 38 & 42 & 38 & 49 & 44 & 45 & 36 & 51 \\
\hline & $\%$ & 32,1 & 24,0 & 26,0 & 23,1 & 31,8 & 29,1 & 30,4 & 26,8 & 35,6 \\
\hline \multirow{2}{*}{$\geq 1500$ г } & № & 91 & 115 & 115 & 118 & 99 & 98 & 96 & 94 & 82 \\
\hline & $\%$ & 63,3 & 72,7 & 70,9 & 72 & 64,3 & 65 & 64,9 & 70,1 & 57,3 \\
\hline Всего & № & 143 & 158 & 162 & 164 & 154 & 151 & 148 & 134 & 143 \\
\hline $\begin{array}{c}\text { Индекс } \\
\text { неонатальных } \\
\text { трансферов }\end{array}$ & $\%$ & 0,39 & 0,43 & 0,43 & 0,43 & 0,40 & 0,37 & 0,37 & 0,34 & 0,36 \\
\hline
\end{tabular}

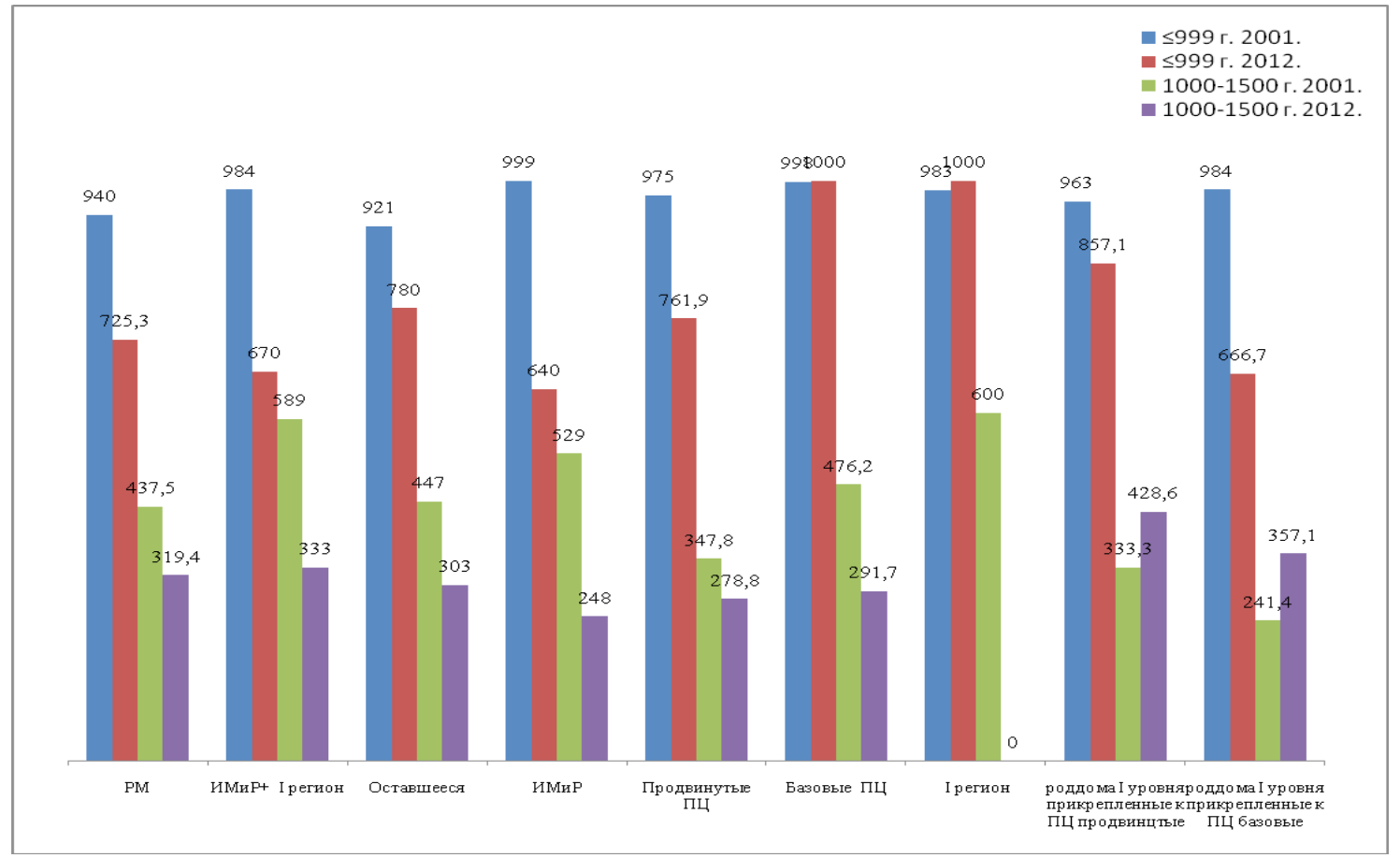

\section{Рис.4. Динамика показателя специфической смертности в весовой категории до 1000 г и 1000-1500 г в 2001 г. и 2011-2012 гг. по уровням региональной системы}

Одним из индикаторов эффективности регионализации является уменьшение количества случаев мертворождения и ранней неонатальной смертности в ПЦ І уровня. Сокращение в 2 раза разницы показателей перинатальной смертнос- ти между ПЦ II уровня и I уровня к 2013 году свидетельствует о хорошем функционировании региональной системы и о повышении качества оказания перинатальной помощи. 


\section{Выводы:}

1. Региональная перинатальная система в течение 15 лет функционирования доказала свою высокую эффективность одновременно с внедрением национальных политик, эффективных технологий перинатального ухода, протоколов и обучения медицинского персонала для улучшения материнского и неонатального ухода.

2. Проведенный анализ свидетельствует о динамики роста количества родов в ПЦ II и III уров- ня и их снижении на I уровне, преимущественном рождении недоношенных новорожденных в ПЦ II и III уровня, централизации родов беременных с риском, требующем экстренной помощи, что позволило уменьшить уровень перинатальных потерь. В то же время, вырос показатель смертности новорожденных на III уровне ухода в связи с направлением на данный уровень наиболее тяжелых новорожденных, а также недоношенных новорожденных с экстремально низким весом при рождении.

\section{Литература}

1. Lawn J. The Healthy Newborn / J. Lawn, BJ. McCarthy, SR. Ross // A Reference Manual for Program Managers, 2001.- 434 p.

2. Neonatal Survival: a call for action / J.Martines, VK.Paul, ZA.Bhutta [et al.] // The Lancet.-2005.-Vol. 365, Issue 9465.-P.1189-1196.

3. MPS/PEPC 3rd Task Force Making Pregnancy Safer/ Promoting Effective Perinatal Care From evidence to practice Verona, Italy, 22 - 24 October, 2003.-33 p.

4. The Government of the Republic of Moldova. The Third Millennium Development Goals Report [Електронний ресурс].- 2013.- p. 93.-Режим доступу: http://www.gov.md/.

5. Стратулат П.М. Региональная система оказания перинатальных и неонатальных медицинских услуг в Республике Молдова / П.М. Стратулат, А.М. Куртяну, Т.Н. Карауш // Международная заочная науч.практ. конф. «Современная медицина: тенденции развития»: м-лы конф.- Издательство ЭКОР-КНИГА, Новосибирск, 2012.-С.109-117.

6. New decision rules: regionalization in perinatal care and indications for perinatal transfer / R. Agostino, A. Antsaklis, G. Breart [et al.] // Prenat Neonatal Med.- 1999.-Vol.4.-P.104-7.

7. Ghidul B Naţional de Perinatologie „Sistemul perinatal regionalizat: niveluri şi conţinut” / P. Stratulat, V. Friptu, L. Eţco [şi al.].- Chişinău, 2006.-165 p.

\section{РЕГІОНАЛЬНА НЕОНАТАЛЬНА ДОПОМОГА В РЕСПУБЛІЦІ МОЛДОВА}

\section{А.М. Куртяну}

\author{
Громадський Медичний заклад \\ Інститут Матері і Дитини \\ (м. Кишинів, Республіка Молдова)
}

Резюме.Одним 3 напрямків Національної програми щодо поліпшення та модернізації медичної перинатальної допомоги (1998-2014рр.) було впровадження трирівневої регіональної системи неонатальної допомоги, що складається 327 перинатальних центрів (ПЦ) І рівня, 10 ПЦ II рівня і одного ПЦ III рівня.

Мета роботи: вивчити накопичений досвід впровадження системи регіональної медичної неонатальної допомоги шляхом комплексного вивчення регіональної диференціації розподілу пологів і показників перинатальної смертності.

Матеріали та методи. Була вивчена народжуваність і показники перинатальної смертності за період 2001 - 2013 рр. за рівнями перинатальної допомоги і розрахований індекс неонатальних трансферів (ІНТ).

Результати дослідження. Аналіз розподілу пологів показує збільшення питомої ваги прийнятих пологів із загальної їх кількості на III та II рівні догляду: 9,6\% у 2001 р. у порівнянні з 14,8\% в 2013 р. (III рівень) і 38,8\% у 2001 р. у порівнянні 3 $50,6 \%$ в 2013 р. (II рівень). Навпаки,\% прийнятих

\section{REGIONAL NEONATAL CARE IN THE REPUBLIC OF MOLDOVA}

\section{A. M. Curtianu}

\author{
Public Health Establishment «Mother \\ and Child Institute» \\ (Chisinau, Republic of Moldova)
}

Summary. One of the directions of the National Program to improve and modernize perinatal care (1998-2014) was the introduction of a three-level regional system for neonatal care consisting of 27 perinatal centers (PCs) of level I, 10 PCs of level II and one PC of level III.

Objective: to study the experience of the regional neonatal care system implementation via analysis of differentiation of births distribution and perinatal mortality (PM) indicators.

Materials and methods. Birth rate and PM by the levels of perinatal care for the period of 2001-2013 were studied and the index of neonatal transfers was calculated.

Results of the study. The analysis of births distribution shows that from 2001 to 2013 the proportion of births on IIIrd and IInd levels increased, out of their total amount: $9,6 \%$ in $2001 \mathrm{vs}$. $14,8 \%$ in 2013 (III level) and 38,8\% in 2001 vs. 50,6\% in 2013 (II level). On the other hand, \% of births at Ist level decreased from $46,2 \%$ to $34,6 \%$. On the level III of perinatal care the number of children born alive and weighing $<1500 \mathrm{~g}$ has increased by 3 times (from 
пологів на I рівні знизився з 46,2\% до 34,6\%. На III рівні збільшилася в 3 рази (з 1,33\% до 2,71\%) кількість дітей, народжених живими з вагою <1500 г, на I та II рівні відзначається значне зниження показника. У 2004-2012 рр. число дітей, народжених до 32 н.б. на I та II рівні і були доставлені на III рівень 3 вагою $\leq 999$ г, збільшилася з 4,2\% до 7,0\%; 3 вагою 1000-1499 г не змінилося (32,1\% і $35,6 \%)$, а з вагою $\geq 1500$ г знизилося з $63,3 \%$ до 57,3\%. IНТ варіював від 0,39\% до 0,36\% за цей період, що вказує на гарне функціонування служби транспортування новонароджених.

Висновки: Регіональна перинатальна система довела свою високу ефективність разом з впровадженням національних політик, ефективних технологій перинатального догляду та протоколів, заснованих на доказах, а також навчання медичного персоналу для поліпшення материнського і неонатального догляду.

Ключові слова: регіоналізація; рівень догляду; новонароджений; напрямок; транспортування.
$1,33 \%$ to $2,71 \%$ ), on the levels I and II a significant decline of this indicator was marked. During 20042012, the number of children born before $32 \mathrm{w.g}$. on the levels I and II, who were delivered on the level III of care with birth weight $(\mathrm{BW}) \leq 999 \mathrm{~g}$ increased from $4,2 \%$ to $7,0 \%$, with BW $1000-1499 \mathrm{~g}$ the number did not change $(32,1 \%$ and $35,6 \%)$ and with $\mathrm{BW}$ $\geq 1500 \mathrm{~g}$ decreased from $63,3 \%$ to $57,3 \%$. The index of neonatal transfers ranged from $0,39 \%$ to $0,36 \%$ during this period, which is indicative of a satisfactory functioning of newborns transportation service.

Conclusions: The regional perinatal system has proven to be very effective along with the implementation of national policies, effective technologies of perinatal care and evidence-based protocols, as well as training of medical personnel to improve maternal and neonatal care.

Keywords: regionalization; level of care; newborn; referral; transportation. 